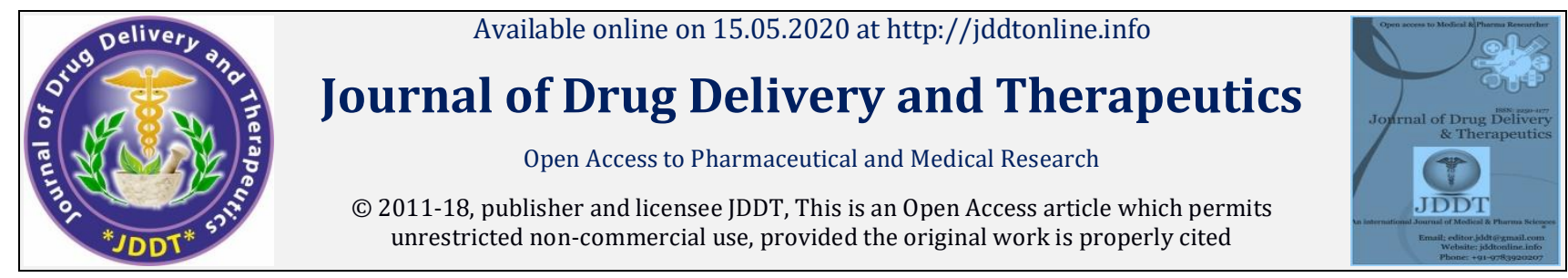

Open@Access

Research Article

\title{
Synthesis and Physicochemical Characterization of Banana Starch Tartrate and its Application as Disintegrant in Telmisartan Tablets
}

\author{
Abhijeet V. Puri*, Prakash D. Khandagale, Ankita U. Tiwari, Rekhadevi H. Chaudhary, Sonam B. Kartan \\ Department of Pharmacognosy, St. John Institute of Pharmacy and Research, Vevoor, Manor Road, Palghar (E), Dist-Palghar-401404 (M. S) India
}

\begin{abstract}
The present investigation was aimed to isolate banana starch (BS), synthesis of banana starch tartrate (BST), characterization, and application as a novel disintegrant in telmisartan tablets. Starch tartrate was synthesized by the esterification process by the treatment of tartaric acid on the backbone of the BS. Synthesized BST was found to be fine, slightly free-flowing and crystalline powder. The synthesized BST was subjected to Scanning Electron Microscopy (SEM) and micrometric evaluation. Flow properties of BS and BST were determi ned as an angle of repose, bulk density, tapped density, Carr's index, Hausner's ratio, etc. BST exhibited good swelling properties and showed no gelling at $100^{\circ} \mathrm{C}$ but it was transformed into a clear solution. Fourier transform infrared spectra (FTIR) did not show the presence of any significant interaction between BST and Telmisartan(T). The direct compression technique was employed in formulating telmisartan tablets using BST sodium starch glycolate and crospovidone as a disintegrant. Tablets were comparatively evaluated for weight variation, thickness, hardness, friability, and disintegration. The tablets formulated using BS and BST passed prescribed evaluation tests for weight variation, friability, hardness, and thickness. The tablets formulated using BST as disintegrant gave optimum disintegration compared to those tablets containing sodium starch glycolate and crospovidone sodium super disintegrants. Evaluations indicated that synthesized BST shows qualitatively and qua ntitatively good disintegration characteristics in comparison to super disintegrants in telmisartan tablet formulation. These results suggest that the synthes ized BST could be used as a novel semi-synthetic disintegrant in dispersible tablet formulations.
\end{abstract}

Keywords: Banana Starch, Banana Starch tartrate, Telmisartan, Superdisintegrant

Article Info: Received 12 March 2020; Review Completed 10 April 2020; Accepted 21 April 2020; Available online 15 May 2020 Cite this article as:

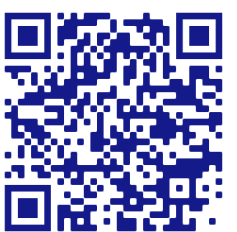

Puri AV, Khandagale PD, Tiwari AU, Chaudhary RH, Kartan SB, Synthesis and Physicochemical Characterization of Banana Starch Tartrate and its Application as Disintegrant in Telmisartan Tablets, Journal of Drug Delivery and Therapeutics. 2020; 10(3):65-72 http://dx.doi.org/10.22270/jddt.v10i3.4089

*Address for Correspondence:

Abhijeet V. Puri, St. John Institute of Pharmacy and Research, Vevoor, Manor Road, Palghar (E), Dist-Palghar-401404 (M. S) India

\section{INTRODUCTION}

Starch is polymeric substance derived from carbohydrate and composed of long-chain polysaccharides containing amylose and amylopectin units with branched-chain 1. Starches are used as excipients in pharmaceuticals principally derived from corn, wheat, and potato which are monographed in some pharmacopeia. Starch is one of the most commonly used binders, lubricant, and disintegrant in the formulations of solid dosage forms. The swelling ability of the starch is accountable for its disintegration properties. Disintegrating agents exist as the hydrophilic ingredients when interacting with saliva or gastric fluid absorbs water, swells that cause disintegration of tablets ${ }^{2}$. Even though Corn starch is broadly used in pharmaceutical formulations, starches from supplementary botanical sources have revealed diverse functional properties such as swelling, gelling, and water binding capability. As influential disintegrant starches are valuable in the formulation of insoluble drug substances ${ }^{3}$. The unripe fruit of banana is considered as a source of eco-friendly materials. The pulp of unripe banana fruit is made up of $60-80 \%$ starch based on dry weight with a percentage that is equal to any other source of starch 4,5 . Modified starches have a comprehensive range of properties from the binder to disintegrant and preventing moisture entrapment in tablet formulations. The modified starches shown improved stability, paste clarity, increased resistance to high temperature, high shear, low $\mathrm{pH}$, and increases freeze-thaw stability ${ }^{6}$. Chemical modification of starch commonly implicates oxidation, hydrolysis or etherification of the available hydroxyl groups on the $\alpha$-Dglucopyranosyl units that form a starch polymer. To improve specific properties chemical modifications are carried out employing techniques such as oxidation, cross-linking, degrading and substitution reactions. As starch is a polyfunctional compound cross-linking of starch can be achieved. A low degree of substitution could result in key changes in starch functionality. In the pharmaceutical sector, 
modified starches have found great use in the development of conventional and novel drug delivery systems ${ }^{7,8}$. Acid treatment of starch devoid of significant changes like starch granules results in the formation of modified starch that imparts important properties that have commercial value. This type of starch modification mostly occurs due to the attack of the acid against an amorphous unit of the starch. An assumption made based on electron microscopic identification indicated that electron-thin rings of starch granules of the amorphous section are completely disintegrated by acid modification with restricted disintegration of electron-dense rings ${ }^{9}$. Telmisartan belongs to a class of drugs called angiotensin receptor blockers (ARBs) it is an angiotensin II receptor antagonist. It is used in the treatment of high blood pressure. By blocking the action of angiotensin, telmisartan widens blood vessels (vasodilator) and reduces blood pressure. It belongs to class II of a pharmaceutical classification system of drugs having low solubility and high permeability in the biological systems. Studies have revealed that oral administration has poor bioavailability of about $50 \%$ as it is highly lipophilic with an aqueous solubility of $0.078 \mathrm{mg} / \mathrm{mL}$. It is a challenge for researchers to increase aqueous solubility and dissolution of telmisartan. The easy way to attain the rapid disintegration of tablets is to incorporate super disintegrant with suitable diluents ${ }^{10}$. Superdisintegrants such as croscarmellose sodium, crospovidone and sodium starch glycolate (SSG) are commonly incorporated in tablet formulations to increase the rate of dissolution and thus increase in bioavailability of the drugs. In this study, banana starch tartrate (BST) was synthesized by a novel method. The physicochemical properties as a pharmaceutical excipient were characterized and its potential use as a disintegrant in telmisartan tablets was investigated.

\section{MATERIALS AND METHODS}

\subsection{Materials}

Unripe Banana starch was obtained from the local market and starch was isolated in the laboratory. Telmisartan drug (IPCA Pharma Pvt. Ltd.) and all other chemicals were of analytical grade which was obtained from SIGMA, Loba Chemie Pvt. Ltd., Mumbai, India.

\subsection{Isolation of Starch from the unripe fruit of Banana11,12}

Isolation of starch was carried out by an alkaline extraction technique using sodium hydroxide solution. The unripe banana was carefully washed to remove foreign materials, peeled, weighed and washed. The peeled banana fruits were cut in-to small pieces and pulverized using a homogenizer. The pulp of banana fruits obtained and was mixed with enough quantity of water and then passed through a muslin cloth. Different concentrations of sodium hydroxide were added to separate the starch. Additional sodium hydroxide was eliminated by washing numerous times with deionized water. The filtrate was collected and allowed to settle. The clear supernatant fluid was discarded while sedimented starch was separated, washing with alcohol was given and dried at $40^{\circ} \mathrm{C}$

\subsection{Synthesis of a novel super disintegrant banana starch tartrate ${ }^{13}$}

Initially $10 \mathrm{~g}$ of tartaric acid (TA) and $2 \mathrm{~g}$ of sodium hypophosphite dissolved in $25 \mathrm{~mL}$ of distilled water. To this $10 \mathrm{~g}$ air-dried BS, was added to produce dispersion and this mixture was stirred vigorously with a glass rod. Then the $\mathrm{pH}$ of the solution was adjusted to 3.5 using $10 \mathrm{M}$ sodium hydroxide. This solution was then acclimatized for $16 \mathrm{hrs}$.
The mixture was placed in a hot air oven to dehydrate at $60^{\circ} \mathrm{C}$ until it gets dried. At this point, all surface moisture was removed, and the starch tartrate was washed away with distilled water to get rid of the unreacted tartaric acid. The products of reaction obtained were added to $100 \mathrm{~mL}$ of distilled water and centrifuged. This product was then kept in the oven at $60^{\circ} \mathrm{C}$ until it was dried completely. The reaction scheme for the synthesis of BST is shown in (Figure 1). The BST product was then grounded, the yield was determined by passing through sieve no. \#80.

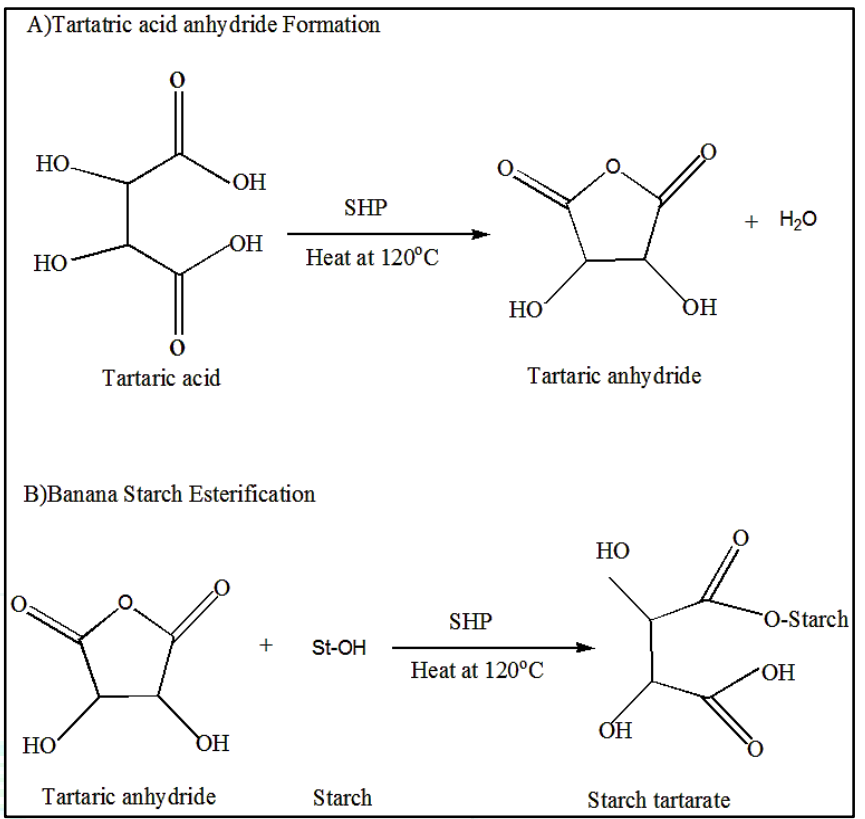

Fig.1:- Scheme for synthesis of Banana Starch Tartrate.

\subsection{Pharmaceutical characterization of Starch and Banana Starch Tartrate}

\subsubsection{Identification test 14,15}

$1 \mathrm{~g}$ of BS and BST tartrate was boiled with $50 \mathrm{~mL}$ of water separately and subjected to identification of carbohydrates (Molish test), carbonyl groups (Tollen's and Benedict's tests) esters (phenolphthalein and hydroxamic acid test), and polysaccharide (Iodine test).

\subsubsection{Particle size determination (Light Microscopy) 16}

A small amount of BS and BST was individually mixed with glycerol. This mixture was mounted separately onto a microscope slide with a coverslip and observed under polarized light microscopy. The mean particle size was determined microscopically using a standardized eyepiece.

\subsubsection{Scanning Electron Microscopy (SEM) ${ }^{17}$}

Grain shapes and the surface structures of the BS and BST were observed by the SEM technique. The sample was mounted on a spherical aluminum stub, coated with gold by using an ion sputter and was examined by SEM at an accelerating potential difference of $20 \mathrm{kV}$.

\section{$\begin{array}{llll}\text { 2.4.4. Fourier Transform Infra-Red } & \text { (FTIR) }\end{array}$ spectroscopy ${ }^{18}$}

FTIR was recorded on samples prepared in potassium bromide (KBr) disks employing a BRUKER FT-IR, (Tokyo, Japan). $\mathrm{KBr}$ disks of samples were prepared at 6-8 tons hydrostatic press and analysed samples between scanning ranges 500 to $4000 \mathrm{~cm}^{-1}$. The compatibility of BST with the selected drug Telmisartan (T) was compared. The presence of additional peaks corresponding to the functional groups was noted. 


\subsubsection{Paste clarity 19}

The clarity (transmittance $\%$ at $650 \mathrm{~nm}$ ) of BS and BST was measured. A $1 \%$ aqueous suspension of starch near-neutral $\mathrm{pH}$ was heated in a boiling water bath for $30 \mathrm{~min}$ with intermittent shaking. After the suspension was cooled for $1 \mathrm{hr}$. at $25^{\circ} \mathrm{C}$, the light transmittance at $650 \mathrm{~nm}$ was read against water blank.

\subsubsection{Moisture content ${ }^{20}$}

A total of $3 g$ quantity each of BS and BST was placed in the oven at $105{ }^{\circ} \mathrm{C}$ for $3 \mathrm{hrs}$. and weighed. Triplicate readings were taken and the mean was calculated. The ratio of the final weight to the initial weight was expressed in terms of percentage.

\subsubsection{Swelling capacity ${ }^{21}$}

The tapped volume occupied by $10 \mathrm{~g}$ of each BS and BST (Vd) in a $100 \mathrm{~mL}$ measuring cylinder was noted. The powder was then added in $85 \mathrm{~mL}$ of deionized water and volume was made up to $100 \mathrm{~mL}$ with deionized water. After $18 \mathrm{hrs}$. of standing, the volume of the sediment, $(V w)$ was noted and the swelling capacity was determined by using the formula;

\section{Swelling capacity $=V w-V d$}

\subsubsection{Ash Value of $\operatorname{starch}^{22}$}

A total of $2 \mathrm{~g}$ quantity of BS and BST was weighed into a silica crucible and incinerated. The determination of ash value was done by measurement of the residue left after complete combustion in a muffle furnace at $550^{\circ} \mathrm{C}$.

\subsubsection{Determination of $\mathrm{pH}^{23}$}

The $\mathrm{pH}$ of $1 \% \mathrm{w} / \mathrm{v}$ slurry of BS and BST in water was determined by digital $\mathrm{pH}$ meter (Lab-India Analytical Instruments Pvt. Ltd., Mumbai, India).

\subsubsection{Solubility ${ }^{24}$}

The solubility of $1 \% \mathrm{w} / \mathrm{v}$ of BS and BST were tested in water, aqueous buffers ( $\mathrm{pH} 1.2,6.8,7.4$ and 7.5) and organic solvents (methanol, chloroform, acetone, and ether) at $30 \pm 0.2^{\circ} \mathrm{C}$

\subsubsection{Viscosity 25}

The relative viscosity of $1 \% \mathrm{w} / \mathrm{v}$ BS and BST dispersion in water was measured using $10 \mathrm{~cm}^{3}$ U-tube Ostwald at $30 \pm 0.2^{\circ} \mathrm{C}$

\subsubsection{Gelling property 26}

The gelling property of BS and BST was estimated by heating $10 \% \mathrm{w} / \mathrm{v}$ dispersion in the water at $60,70,80,90$ and $100^{\circ} \mathrm{C}$ for $15 \mathrm{~min}$ with occasional stirring.

\subsection{Flow properties of starch and starch Tartrate $27,28,29,30$}

\subsubsection{Angle of repose}

It was determined by allowing BS and BST powder to flow through a funnel and fall freely on to a surface. Further addition of powder was stopped as soon as the pile has touched the tip of the funnel. A circle was drawn around the pile without any disturbance. The height and diameter of the resulting cone were measured. The same process was repeated three times and the average value was noted. The angle of repose was calculated by using the following equation: $\operatorname{Tan} \boldsymbol{\theta}=\mathbf{h} / \mathbf{r}$
Where $\mathrm{h}=$ height of the powder cone; $\mathrm{r}=$ radius of the powder.

\subsubsection{Bulk density}

A sufficient quantity of BS and BST was passed through a $1.00 \mathrm{~mm}$ (no.18) screen to disrupt the agglomerates that were formed during storage. Into a dry $250 \mathrm{~mL}$ cylinder, approximately $100 \mathrm{~g}$ of the test sample (M) was introduced. The cylinder was carefully filled and the level of powder was accustomed without compressing and the unsettled apparent volume (Vo) was noted. Bulk density was calculated, in $\mathrm{g} / \mathrm{mL}$.

Using the formula: Bulk density $=\mathbf{M} /$ Vo

\subsubsection{Tapped density}

Accurately weighed quantity of BS and BST was added into a measuring cylinder. Mechanically the cylinder comprising the sample was tapped by elevating the cylinder and permitting it to drop under its weight employing an appropriate mechanical tapped density tester at a minimal rate of $300 \mathrm{drops} / \mathrm{min}$. The cylinder was tapped 500 times and the tapped volume $(V a)$ was measured. The technique was repeated for an added 750 tapings and again the tapped volume was noted as $(V b)$. If the difference between $V a$ and $V b$ was $<2 \%, V b$ was the final tapped volume $(V f)$. If the difference was higher, the tapings were repeated for an additional 1,250 times, and then the tapped density was calculated using the following formula:

\section{Tapped density $=\mathbf{M} / \boldsymbol{V f}$}

Where $\mathrm{M}=$ weight of the sample taken; $\mathrm{Vf}$ = final tapped volume

\subsubsection{Carr's index}

The compressibility index of BS and BST granules was determined using Carr's compressibility index, as follows:

$$
\text { Carr's index }=\frac{\text { (Tapped density-Bulk density) }}{\text { Tapped density }} \times 100
$$

\subsubsection{Hausner's ratio}

The Hausner's ratio of BS and BST was determined using the following formula:

$$
\text { Hausner's ratio }=\frac{\text { Tapped density }}{\text { Bulk density }}
$$

\subsection{Formulation of tablet by direct compaction 31}

The tablets $(200 \mathrm{mg})$ were prepared by direct compaction using drug telmisartan $(20 \mathrm{mg})$, Microcrystalline cellulose (MCC) $50 \% \mathrm{w} / \mathrm{w}$ as a binder, mannitol (Q.S.) as a diluent, Sodium lauryl sulfate (SLS) $1 \% \mathrm{w} / \mathrm{w}$ as a wetting agent, and magnesium stearate $(2.5 \% \mathrm{w} / \mathrm{w})$ as lubricants. The composition of different formulation of telmisartan was prepared in which different super-disintegrants were selected with various combinations. A series of tablets were prepared as control (F1) employing banana starch tartrate BST (F2), Crospovidone (F3) and Sodium starch glycolate (SSG) (F4) as disintegrant at concentrations of $5 \% \mathrm{w} / \mathrm{w}$ separately and combinations of this super-disintegrant with starch tartrate were compared shown in (Table 1). Each ingredient was weighed accurately, blended and compressed into tablets and subjected to evaluation. 
Table 1: Formulation of Telmisartan tablet by direct compression

\begin{tabular}{|l|l|l|l|l|l|l|l|l|}
\hline Sr. No & \multicolumn{1}{|c|}{ Ingredients } & \multicolumn{1}{|c|}{ F1 } & \multicolumn{1}{|c|}{ F2 } & \multicolumn{1}{|c|}{ F3 } & \multicolumn{1}{|c|}{ F4 } & \multicolumn{1}{|c|}{ F5 } & \multicolumn{1}{|c|}{ F6 } & \multicolumn{1}{|c|}{ F7 } \\
\hline $\mathbf{1}$ & Telmisartan & $20 \mathrm{mg}$ & $20 \mathrm{mg}$ & $20 \mathrm{mg}$ & $20 \mathrm{mg}$ & $20 \mathrm{mg}$ & $20 \mathrm{mg}$ & $20 \mathrm{mg}$ \\
\hline $\mathbf{2}$ & MCC & $100 \mathrm{mg}$ & $100 \mathrm{mg}$ & $100 \mathrm{mg}$ & $100 \mathrm{mg}$ & $100 \mathrm{mg}$ & $100 \mathrm{mg}$ & $100 \mathrm{mg}$ \\
\hline $\mathbf{3}$ & Starch Tartrate & - & $2 \mathrm{mg}$ & - & - & - & $2 \mathrm{mg}$ & $2 \mathrm{mg}$ \\
\hline $\mathbf{4}$ & Crospovidone & - & - & $2 \mathrm{mg}$ & - & $2 \mathrm{mg}$ & $2 \mathrm{mg}$ & - \\
\hline $\mathbf{5}$ & SSG & - & - & - & $2 \mathrm{mg}$ & $2 \mathrm{mg}$ & - & $2 \mathrm{mg}$ \\
\hline $\mathbf{6}$ & SLS & $2 \mathrm{mg}$ & $2 \mathrm{mg}$ & $2 \mathrm{mg}$ & $2 \mathrm{mg}$ & $2 \mathrm{mg}$ & $2 \mathrm{mg}$ & $2 \mathrm{mg}$ \\
\hline $\mathbf{7}$ & Magnesium stearate & $6 \mathrm{mg}$ & $6 \mathrm{mg}$ & $6 \mathrm{mg}$ & $6 \mathrm{mg}$ & $6 \mathrm{mg}$ & $6 \mathrm{mg}$ & $6 \mathrm{mg}$ \\
\hline $\mathbf{8}$ & Mannitol & $72 \mathrm{mg}$ & $70 \mathrm{mg}$ & $70 \mathrm{mg}$ & $70 \mathrm{mg}$ & $68 \mathrm{mg}$ & $68 \mathrm{mg}$ & $68 \mathrm{mg}$ \\
\hline TOTAL & & $200 \mathrm{mg}$ & $200 \mathrm{mg}$ & $200 \mathrm{mg}$ & $200 \mathrm{mg}$ & $200 \mathrm{mg}$ & $200 \mathrm{mg}$ & $200 \mathrm{mg}$ \\
\hline
\end{tabular}

MCC.: Microcrystalline cellulose, SSG.: Sodium starch glycolate, SLS.: Sodium lauryl sulfate

\subsection{Evaluation of Tablets}

\subsubsection{Weight variation 32}

The weight variation test of the tablets was determined as per I.P. twenty tablets from each batch were randomly selected weighed individually and average weights were determined.

\subsubsection{Thickness ${ }^{33}$}

The thicknesses of the tablets were determined using a Vernier caliper, 20 tablets from each batch were used and average values were calculated.

\subsubsection{Hardness Test $^{34}$}

Monsanto hardness tester was utilized to determine the hardness of the manufactured tablets. From each batch, five tablets were randomly selected and were subjected to test. The mean of these five tablets was given in the table.

\subsubsection{Friability 35}

Friability is a measure of tablet strength, which can be determined by using Roche friabilator. Ten tablets were selected and the weight was determined. Later these tablets were located in the friabilator and endorsed to make 100 revolutions at $25 \mathrm{rpm}$. These tablets were then sifted, reweighed, and calculated for percent weight loss.

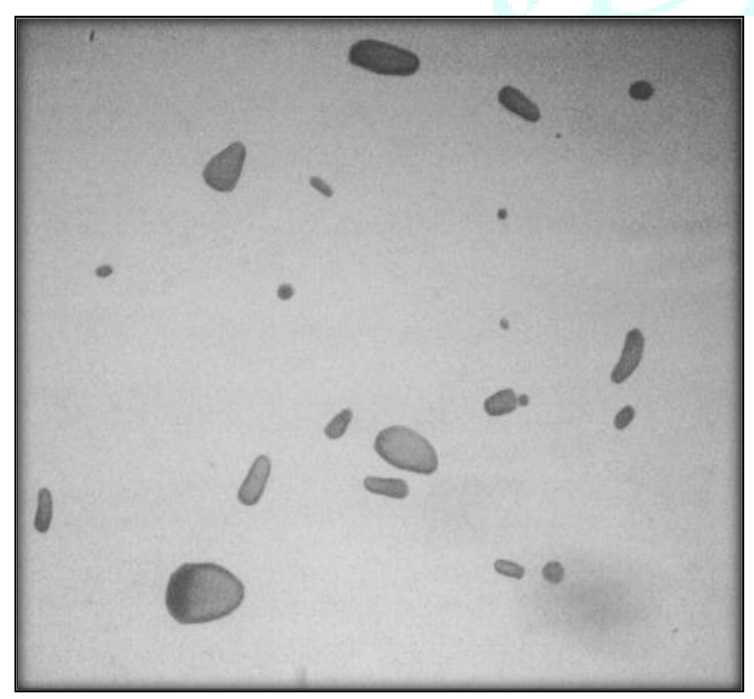

Banana starch

\subsubsection{Disintegration Test 36,37}

Six tablets were taken in the disintegration apparatus. A set of six glass tubes of about 3 inches long with the top opened is held against a 10-mesh screen at the foot end of the basket rack assembly. To test the disintegration time the individual tablet was added in each tube. Later basket rack was placed in a 1litre beaker of water at $37^{\circ} \mathrm{C} \pm 2^{\circ} \mathrm{C}$. A standard motor driver device was used to move the basket assembly up and down over a distance of 5-6 cm at a frequency of 28-32 cycles per minute. The time taken for the individual tablet to break into small particles was noted. To meet the IP standard all particles of the tablet should pass over the 10-mesh screen at a specified time. From this mean disintegration, time was determined.

\section{RESULTS AND DISCUSSION}

Starch extracted from unripe banana fruit had a slight yellowish tinge hence bleaching was carried out with ethanol. On a dry basis, $56.3 \%$ of starch was obtained. Grains of isolated (BS) and (BST) were observed under the light microscope (Figure 2) and an SEM showed in (Figure 3) was the same, Presence of Starches grains with the diameter ranging between $25 \mu$ and $44 \mu$.

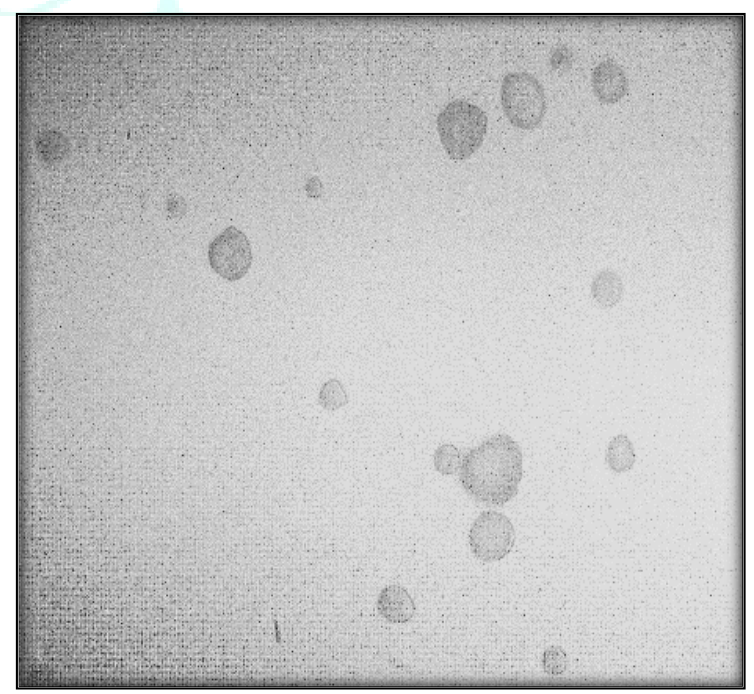

Starch Tartrate

Fig.2:- Light microscopy of BS \& BST 


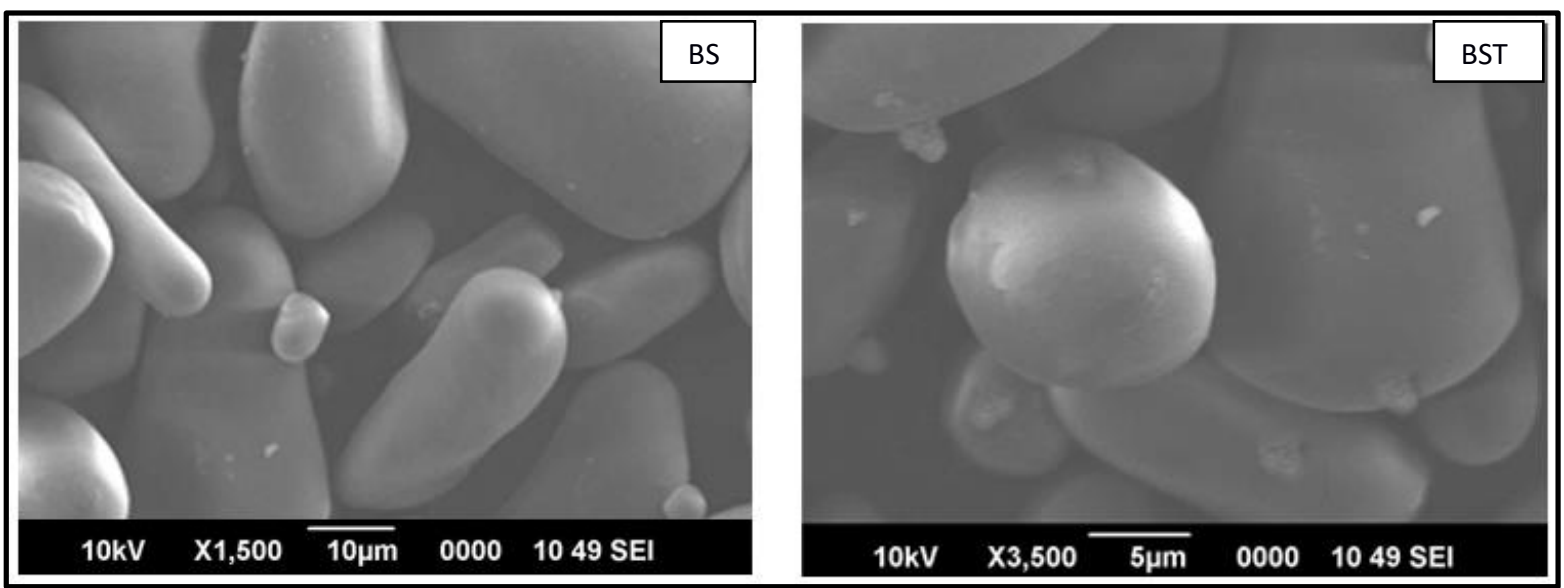

Fig. 3:- Morphology of the BS \& BST as determined by SEM

The shape was regular with an oval appearance. The surface of granules appeared to be smooth and there was no evidence of any fissure. (BST) showed several cracks and fissures on its surface. The synthesized (BST) was found to be fine, smooth, free-flowing amorphous powder, nonhygroscopic powder, with no characteristic odour or taste and with a yield of $85.4 \%$. An equal amount of (BS) and Tartaric Acid (TA) was optimum for the synthesis of banana starch tartrate. The (BST) did not melt during heating but charred at $180 \pm 0.8^{\circ} \mathrm{C}$. The synthesized (BST) confirmed test for the presence of carbohydrates, carbonyl groups, and esters. (BST) was insoluble in water, organic solvents (methanol, chloroform, ether, and acetone), and aqueous buffers (pH 1.2, 6.8, 7.4 and 7.5). No gelling was observed even at $80^{\circ} \mathrm{C}$ but converted to a clear solution having a swelling index of 1.88 that has shown faster disintegration when incorporated in telmisartan tablets formulation. Other properties are summarised (Table 2).

Table 2:- Pharmaceutical characterization of BS and BST

\begin{tabular}{|c|c|c|c|}
\hline Sr. No. & Characterization of Starch & Banana Starch & Banana Starch tartrate \\
\hline 1. & State & Amorphous powder & Amorphous powder \\
\hline 2. & Odour & No odour & A characteristic odour \\
\hline 3. & Taste & Tasteless & Bitter \\
\hline 4. & Colour & White & White \\
\hline 5. & Carbohydrates (Molish's test) & $+\mathrm{Ve}$ & $+\mathrm{Ve}$ \\
\hline 6. & Carbonyl group (Tollen's test) & $+\mathrm{Ve}$ & $+\mathrm{Ve}$ \\
\hline 7. & Esters (Phenolphthalein test) & $+\mathrm{Ve}$ & $+\mathrm{Ve}$ \\
\hline 8. & Iodine test & $+\mathrm{Ve}$ & $+\mathrm{Ve}$ \\
\hline 9. & $\begin{array}{l}\text { Projected diameter } \\
\text { (optical microscopy) }\end{array}$ & $34.3 \pm 2.1 \mu \mathrm{m}$ & $42.8 \pm 3.2 \mu \mathrm{m}$ \\
\hline 10. & Average Grain size $(\mu)$ & $38.04 \mu \mathrm{m}$ & $42.8 \mu \mathrm{m}$ \\
\hline 11. & Paste clarity & $10.6 \%$ & $12.91 \%$ \\
\hline 12. & Moisture content & $10.0 \pm 2.2 \%$ & $18.0 \pm 1.8 \%$ \\
\hline 13. & Loss on drying & $12.2 \pm 3.6 \%$ & $16.0 \pm 2.3 \%$ \\
\hline 14. & Swelling capacity & $2.17 \pm 0.72$ & $1.88 \pm 0.36$ \\
\hline 15. & Ash Value $(\% \mathrm{w} / \mathrm{w})$ & $1.2 \pm 0.8$ & $1.8 \pm 0.3$ \\
\hline 16. & Solubility & $\begin{array}{l}\text { Insoluble in aqueous and } \\
\text { organic solvents }\end{array}$ & $\begin{array}{l}\text { Insoluble in aqueous and } \\
\text { organic solvents }\end{array}$ \\
\hline 17. & Viscosity & $2.8643 \mathrm{cps}$ & $2.1662 \mathrm{cps}$ \\
\hline 18. & Gelling property & $\begin{array}{l}\text { Gelling at } 80^{\circ} \mathrm{C} \text { a turbid } \\
\text { solution }\end{array}$ & $\begin{array}{l}\text { No gelling at } 80^{\circ} \mathrm{C} \text { a clear } \\
\text { solution }\end{array}$ \\
\hline 19. & Melting point & $\begin{array}{l}\text { Did not melt } \\
\text { but charred at } 160^{\circ} \mathrm{C}\end{array}$ & $\begin{array}{l}\text { Did not melt } \\
\text { but charred at } 180^{\circ} \mathrm{C}\end{array}$ \\
\hline 20. & Angle of repose & $23.21^{\circ} \pm 1.24$ & $19.29^{\circ} \pm 0.80$ \\
\hline 21. & Bulk density $(\mathrm{g} / \mathrm{cm} 3)$ & $0.51 \pm 0.32$ & 0.55 \\
\hline 22. & Tapped density (g/cm3) & $0.61 \pm 0.21$ & 0.90 \\
\hline 23. & Compressibility index & 14.23 & 12.86 \\
\hline 24. & Carr's index (\%) & $17.91 \pm 1.13$ & 38.9 \\
\hline 25. & Hausner's ratio & $1.21 \pm 0.16$ & 1.63 \\
\hline
\end{tabular}


The Fourier-transform infrared spectroscopy (FTIR) spectrum of Banana Starch (BS) Banana Starch tartrate (BST), Telmisartan (T), Telmisartan and starch tartrate (TBST) is shown in Figure 4.

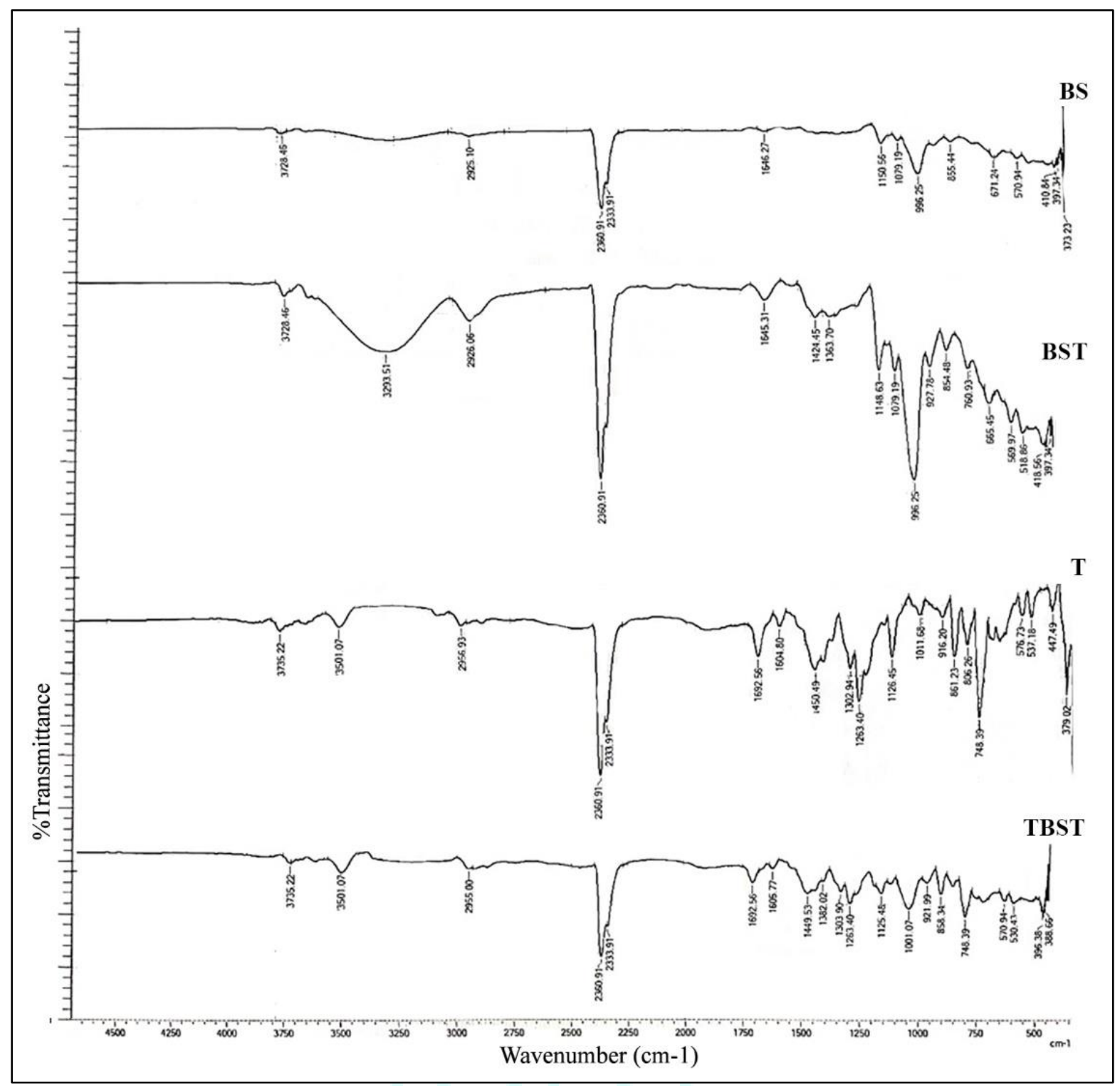

Fig.4:- Fourier-transform infrared spectroscopy (FTIR) of BS, BST, T, and TBST

The FTIR spectra of (BS) showed peaks at wave numbers 765-930, 1159, 1425, 1646, 2130, 2931 and $3422 \mathrm{~cm}^{-1}$ confirming the polysaccharide nature of the (BS). Spectra of (BS) showed three characteristics peaks between $900 \mathrm{~cm}^{-1}$ and $1159 \mathrm{~cm}^{-1}$, indicating the occurrence of $\mathrm{C}-0$ stretching. A prominent band appeared at $930 \mathrm{~cm}^{-1}$, which showed sensitivity to water. The peak at $1159 \mathrm{~cm}^{-1}$ may be referred to as anhydrous glucose ring $\mathrm{C}-\mathrm{O}$ stretch of $\mathrm{C}-\mathrm{O}-\mathrm{H}$ in starch. The band at $1646 \mathrm{~cm}^{-1}$ attributed to deformation vibrations of hydroxyl groups. The peak near $2931 \mathrm{~cm}^{-1}$ showed stretching vibration of $-\mathrm{CH} 2$. The peaks at about $3422 \mathrm{~cm}^{-1}$ are characteristics of hydroxyl group stretching vibration. The spectra (BST) showed peaks absorption at $1691 \mathrm{~cm}^{-1}$ characteristic peaks of ester, so it can be concluded that starch tartrate was formed when starch was allowed to react with tartaric acid. A typical FTIR spectrum of telmisartan (T) exhibits at $3501 \mathrm{~cm}^{-1}$ (N-H stretch) and $1692.58 \mathrm{~cm}^{-1}$ Carboxylic acids $(\mathrm{COOH})$ was observed for the $\mathrm{C}=0$ stretching band $2955 \mathrm{~cm}^{-1}$ (aliphatic C-H stretch), and a weaker C-O stretch around $1263 \mathrm{~cm}^{-1}$, whereas the carboxylate group ( $\left.\mathrm{COO}^{-}\right)$exhibits two characteristics coupled carbonyl absorption band at $1605 \mathrm{~cm}^{-1}$ (asymmetric) and around $1450 \mathrm{~cm}^{-1}$ (symmetric) presence of $\mathrm{C}=\mathrm{C}$ aromatic group. The carbonyl stretches of the carboxylic acid of telmisartan were observed at $1692 \mathrm{~cm}^{-1}$, $3546 \mathrm{~cm}^{-1}$ (N-H stretch), which is not affected and appeared at the same in (TBST). The presence of all these peaks and the non-appearance of other new peaks in the complex of (TBST) indicate there is surely no chemical interaction amongst banana starch tartrate and telmisartan. 
Table 3: Evaluation of Telmisartan Tablets

\begin{tabular}{|l|c|c|c|c|c|c|}
\hline $\begin{array}{c}\text { Sr. } \\
\text { No }\end{array}$ & Batch & $\begin{array}{c}\text { Weight } \\
\text { variation } \\
(\mathrm{n}=20)\end{array}$ & $\begin{array}{c}\text { Thickness } \\
\mathbf{( m m}) \\
(\mathrm{n}=10)\end{array}$ & $\begin{array}{c}\text { Hardness } \\
\left(\mathbf{k g} / \mathbf{~ c m}^{2}\right) \\
(\mathrm{n}=6)\end{array}$ & $\begin{array}{c}\text { Friability (\%) } \\
(\mathrm{n}=20)\end{array}$ & $\begin{array}{c}\text { Disintegration } \\
\text { Time (Sec) } \\
(\mathrm{n}=6)\end{array}$ \\
\hline 1. & F1 & $4.0 \pm 0.8$ & $3.02 \pm 0.05$ & $4.8 \pm 0.04$ & $0.95 \pm 0.04$ & $512 \pm 37$ \\
\hline 2. & F2 & $3.5 \pm 0.4$ & $3.01 \pm 0.01$ & $3.2 \pm 0.07$ & $0.76 \pm 0.02$ & $58 \pm 43$ \\
\hline 3. & F3 & $3.8 \pm 0.2$ & $3.03 \pm 0.04$ & $2.5 \pm 0.09$ & $0.68 \pm 0.01$ & $42 \pm 09$ \\
\hline 4. & F4 & $2.5 \pm 0.1$ & $3.05 \pm 0.02$ & $2.4 \pm 0.07$ & $0.83 \pm 0.04$ & $38 \pm 08$ \\
\hline 5. & F5 & $3.5 \pm 0.3$ & $3.04 \pm 0.02$ & $3.6 \pm 0.03$ & $0.73 \pm 0.03$ & $42 \pm 11$ \\
\hline 6. & F6 & $3.0 \pm 0.2$ & $3.01 \pm 0.01$ & $2.5 \pm 0.05$ & $0.86 \pm 0.01$ & $37 \pm 21$ \\
\hline 7. & F7 & $2.2 \pm 0.5$ & $3.02 \pm 0.04$ & $2.5 \pm 0.08$ & $0.66 \pm 0.02$ & $36 \pm 06$ \\
\hline
\end{tabular}

All values are mean \pm SD.

The bulk density, angle of repose and compressibility index of both (BS) and (BST) were comparable. In all the cases the values of angle of response were $\leq 30^{\circ}$, which indicates that all the (BS) and (BST) was free-flowing (Table 2). Evaluation of (BST) showed a significant increase in bulk and tapped density with an increase in the concentration of (BST) and the good correlation was observed between concentrations of super disintegrants. As the mixture was free flowing, all the tablets that were obtained were of uniform weight due to homogeneous die fill. The unintended degree of the strength of a tablet is its tensile strength. Greater tensile strength and lower friability were observed in this study which implies a good strength to tablets that were prepared using (BST). Telmisartan tablets formulated by using banana starch, banana starch tartrate, crospovidone, sodium starch glycolate, and its combination passed the friability test and was found to be well within acceptable limits for all the tablet formulation. The friability test showed that the banana starch tartrate tablets had similar binding strength compared to super disintegrant containing tablets (Table 3). Weight variation test exhibited no tablet deviating from average weight by $4.2 \%$. Thus all tablets have passed the weight variation test as per the official limit. The disintegration time of banana starch tartrate tablets was almost similar at all the concentrations employed compared to those of super-disintegrants which may be due to higher swelling capacity (Table 2). Swelling capacity alone or their combination is the basic properties of disintegration. Though gelling of superficial particles delays further penetration of dissolution medium into the tablet and avoids disintegration. The rapid disintegration of telmisartan tablets formulated using (BST) may perhaps be owing to its hydrophilic nature that rendered by the presence of a free $\mathrm{COOH}$ group of (TA). This perhaps facilitated the diffusion of water into the tablets by capillary action, therefore, creating pores that lead to quick disintegration.

\section{CONCLUSION}

The work provides a detailed report of some insights into the relative effectiveness of (BST) as a disintegrating agent in comparison to super disintegrants. The results indicated that BS presented a difference in physic-chemical properties that can be caused by starch granule size and morphology. The disappearance of pink colour in the ester test confirmed the presence of ester, i.e., (BST). As the (BST) was amorphous, smooth, free-flowing powder and it had got all the characteristics of super disintegrants it was concluded that the (BST) can be used as a novel super disintegrant in the tablets formulation. It can be concluded that in this study (BST) was synthesized by treating (BS) with tartaric acid
(TA) at elevated temperatures in semi-dry condition. The prepared (BST) showed promising physicochemical properties suggesting suitability as a disintegrant in tablet formulations of poorly soluble drug telmisartan. Preserving its low swelling capacity, (BST) has presented much superior tablet disintegrating properties when compared with sodium starch glycolate and crospovidone. Thus it can be concluded that banana starch tartrate could be employed as a promising semi-synthetic disintegrant in tablets formulation.

\section{ACKNOWLEDGMENT}

The authors would like to thank Principal, Dr. (Mrs.) Savita J. Tauro, St. John Institute of Pharmacy and Research, Palghar for the generous support and providing necessary facilities to carry out the present research work. We sincerely express gratitude to Mr. Albert W. D'Souza, Chairman of Adel Education Trust, Palghar for his motivation and encouragement.

\section{CONFLICT OF INTEREST}

The authors declare no conflict of interest.

\section{ABBREVIATIONS}

BS-Banana Starch

TA-Tartaric acid

BST- Banana Starch Tartare

T- Telmisartan

TBST- Telmisartan and Starch Tartrate

MCC- Microcrystalline Cellulose,

SSG- Sodium Starch Glycolate

SLS- Sodium Lauryl Sulfate

FTIR - Fourier Transform Infrared Spectra

SEM- Scanning Electron Microscopy

\section{REFERENCES:}

1. Lu DR, Xiao CM, Starch-based completely biodegradable polymer materials. Material Science and Engineering, 2009; 3(6):366-75.

2. Puri AV, Puranik VK, Kamble MD, Tauro, S.J. Formulation and evaluation of diclofenac sodium tablet using isolated starch from unripe papaya fruits as disintegrants. Indo Am. J. Pharm. Res., 2013; 3(11):9183-89.

3. Martínez ESM, Méndez MAA, Solís AS, Vieyra H. Thermoplastic biodegradable material elaborated from unripe banana flour 
reinforced with metallocene-catalyzed polyethylene. Polym. Eng. Sci., 2015; 55:866-74.

4. Tomasik P, Schilling CH. Chemical modification of Starch. Adv Carbohyd Chem B., 2004; 59:175-03.

5. Lowenthal W. Mechanism of action of starch as a tablet disintegrates. Pharm Acta Helv, 1973; 48(11):589-09.

6. Sanghvi PP, Collins CC, Sheila AJ. Evaluation of pre flow modified starches as new direct compression excipients: tableting characteristics. Pharma Res., 1993; 10(11):1597-03.

7. Lewicka K, Siemion P, Kurcok P. Chemical modifications of starch: Microwave effect. Int. J. Polym., Sci 2015; 2015:867697.

8. Shogren RL. Rapid preparation of starch esters by high temperature/pressure reaction. Carbohydr. Polym., 2003, 53:319-26.

9. Rohwer RG, Klem RE, Acid modified starch: production and uses. in: starch chemistry and technology, Whistler, R.L., J.N BeMiller, and E.F. Paschall, (Eds.). New York, Academic Press; 1984. P. 529-41.

10. Benson SC, Pershadsingh HA, Ho CI, Chittiboyina A, Desai P, Pravenec M, Qi N, Wang J, Avery MA, Kurtz TW. Identification of telmisartan as a unique angiotensin II receptor antagonist with selective PPARgammamodulating activity. Hypertension., 2004; 43: 993-1002.

11. Zhang P, Whistler RL, BeMiller JN, Hamaker BR. Banana starch: production, physicochemical properties, and digestibility: A review. Carbohydr. Polym., 2005; 59:443-58.

12. Pal S, Mal D, Singh R.P, Cationic starch: an effective flocculating agent. Carbohydrate Polymers., 2005; 59(4):417-23.

13. Salam A, Pawlak JJ, Venditti RA, El-Tahlawy K. Synthesis and characterization of starch citrate-chitosan foam with superior water and saline absorbance properties Biomacromolecules. 2010; 11(6):1453-59.

14. Odeniyi MA, Onu RN, Adetunji OA. Evaluation of bioadhesive properties of natural and modified banana starches. East and Central African Journal of Pharmaceutical Sciences., 2011; 14:34-42.

15. Harborne JB. Textbook of phytochemical methods. A guide to modern techniques of plant analysis. 5th ed. London: Chapman and Hall Ltd; 1998.P.91.

16. Millan-Testa C.E, Mendez-Montevallo M.G. et.al. Determination of the molecular and structural characteristics of Okenia, mango, and banana starches. J. Agric. Food Chem., 2005; 53:495-01.

17. Pal S, Mal D, Singh RP. Characterization of cationic starch: An efficient flocculating agent. J. Appl. Polym. Sci., 2008; 108(4):2674-81.

18. Wang PX, Wu X, Dong-Hua X, Kun X, Ying T, Xi-bing D, et. al. Preparation and characterization of cationic corn starch with a high degree of substitution in dioxane-THF-water media. Carbohydr Res., 2009; 344(7):851-55.

19. Wattanachant S, Muhammad S.K.S, Mat Hashim D, Rahman R.A. Suitability of sago starch as a base for dual-modification, Songklanakarin, J. Sci. Technol., 2002; 24(3):431-38.

20. Onah JO, Bristol OD. Studies on the physicochemical properties of starches from Cajanus cajan and Digitaria exilis, J. Pharm. Res. Dev., 1999; 4(2):73.
21. Arunraj R. Comparative evaluation of potato starch and banana powder as disintegrating agents in aceclofenac tablet formulation International Journal of Pharmacy and Pharmaceutical Sciences., 2013; 5(2):204-07.

22. Attama AA, Adikwu MU, Physicochemical properties of starch derived from Tacca involucrate, Nig. J. Nat. Prod. And Med. 1999; 3:71.

23. Santosh Kumar R, Satya Yagnesh TN. Design, optimization, and evaluation of ibuprofen fast dissolving tablets employing starch tartrate-a new super disintegrant, J. drug deliv. ther., 2019; 9(2):160-69.

24. Moore GRP, Canto LR, Edna A R, Soldi V. Cassava and corn starch in maltodextrin production. Química Nova., 2005; 28(4):596-600.

25. Santosh Kumar R, Chowdary KP, Preparation and characterization of Starch-Urea-Borate: A new floating polymer, J. drug deliv. ther., 2019; 9(2):280-84.

26. Attama, A A, Nnamani PO, Mbonu I K, Adiku MU. Effect of hypochlorite oxidation on the physicochemical properties of gladiolus starch. J. Pharm. Allied Sci, 2003; 1(1):28-35.

27. Remya KS, Beena P, Bijesh PV, Sheeba A. Formulation development, evaluation and comparative study of effects of super disintegrants in cefixime oral disintegrating tablets. J Young Pharm., 2010; 2(3):234-39.

28. Obitte NC, Chukwu A. Preliminary studies on Tacca involucrate starch, West African Journal of Pharmacy 2007; 20(1):8-13.

29. Kushwaha A, Singh PM. Isolation and evaluation of binding properties of cucumber starch, Drug Deliv. Lett., 2018; 8(1):72-77.

30. Loyd VA, Nicholas GP, Howard CA. Ansel's pharmaceutical dosage forms and drug delivery systems. $8^{\text {th }}$ ed. London: Lippincott Williams and Willkins; 2005.P.148-50,227-59.

31. Assaleh FH, Katakam P, Botcha R, Chandu BR, Adiki SK. Synthesis and characterization of starch tartrate and its application as a novel disintegrant in telmisartan tablets. Starch - Stärke., 2014; 66(3-4):409-17.

32. Lachman L, Lieberman HA, Kanig JL. The theory and practice of industrial pharmacy. $3^{\text {rd }}$ ed. Mumbai: Varghese Publishing House; 2009.P.371-72.

33. Puri AV, Gholap AD. Comparative evaluation of papaya and banana starch as a disintegrant in diclofenac sodium tablet formulation. Int. J. Pharm. Biol. Sci., 2018; 8(3):512-22.

34. Jaya S, Chowdary KP, Rao PR. Effect of binders on the dissolution rate and dissolution efficiency of ritonavir tablets. Int. Res. J. Pharm. Appl. Sci., 2012; 2(4):109-13.

35. Indian Pharmacopoeia. $4^{\text {th }}$ ed. Government of India, Ministry of Health and Family Welfare. New Delhi.1996; 692,711.

36. Kushwaha A, Singh PM. Role of naturally isolated pear starch on the bioavailability of famotidine, J. drug deliv. ther., 2019; 9(3):430-35

37. Martin A. Physical Pharmacy. $4^{\text {th }}$ ed. B.I. Waverly. New Delhi; 1993.P. 444. 